\title{
PHOTO-FENTON AND ADSORPTION COMBINED PROCESS FOR DEGRADATION AND REMOVING OF COOMASSIE BRILLIANT BLUE DYE FROM AQUEOUS SOLUTION
}

\author{
A. M. D. CANTELI ${ }^{1}$, D. CARPINE ${ }^{1}$, G. DONÁ ${ }^{1}$, T. A. TAKASHINA ${ }^{1}$, A. de P. SCHEER ${ }^{1}$, L. \\ IGARASHI-MAFRA ${ }^{1}$ \\ ${ }^{1}$ Universidade Federal do Paraná, Departamento de Engenharia Química \\ E-mail para contato: andersonmdcanteli@gmail.com
}

\begin{abstract}
RESUME - Coomassie Brilliant Blue (CBB) is a commonly dye present in the waste of the textile industry. Its use produces waste which must be treated before being discharged into rivers or sewage. Combined processes have been used with efficiency for wastewater treatment. This study aims to evaluate the combined process of photo-Fenton and adsorption for the degradation and removal of the dye CBB in aqueous solution. Initially, the CBB was submitted to photo-Fenton oxidation. Photo-Fenton oxidation degraded $76,9 \%$ of the initial CBB concentration, which was not enough to satisfies the Brazilian legislation. The fixedbed adsorption was conducted for 13 hours, and during all this period the outlet concentration was always lower than the breakpoint, being this concentration in compliance with the legislation. The combined photo-Fenton/Fixed-bed adsorption was effective in the CBB removing (at least 95,9\%).
\end{abstract}

Keywords: Fixed bed; granular activated carbon; waste treatment; combined treatment; oxidation.

\section{INTRODUCTION}

Coomassie Brilhant Blue (CBB) is a non-azo dye commonly present in the waste of the textile industry and also widely used as a reagent for determining protein concentration (e.g. Bradford protein assay). Its continuous dumping into rivers may cause several problems to the ecosystem, such as the inhibit of the sunlight penetration into the water (which reduces the photosynthesis) and unsightly appearance of the water (Wang et al., 2012; Han et al., 2009).

The Brazilian legislation (CONAMA No 430/2011) does not establishes a maximum color values to an effluent can be discharged into receiving bodies. However defines that the effluent should be virtually absent color (which is not noticeable by sight) (Conama, 2014). In this context, is necessary to implement a treatment that can minimize environmental damages.

Some techniques have been studied for CBB removal and/or degradation, such as batch adsorption (Sales et al., 2013; Rauf et al., 2008), photolytic oxidation with $\mathrm{H}_{2} \mathrm{O}_{2}$ (Rauf et al., 2005); photocatalytic decoloration with titanium oxide (Bukallah et al., 2007) and photo-Fenton (Caixeta et al., 2013). None of these papers have reported completed discoloration of the CBB.

Photo-Fenton oxidation is a process that uses hydrogen peroxide and ferrous ion (as a catalyst) in the presence of the light in order to generate hydroxyl radicals $\left(\mathrm{HO}^{\bullet}\right)$ which can destroy organic compounds (Lucas and Peres, 2006). This hydroxyl radical can be formed in tree 
distinct reactions (Equations 1, 2 and 3):

$$
\begin{aligned}
& \mathrm{H}_{2} \mathrm{O}_{2}+\mathrm{Fe}^{2+} \rightarrow \mathrm{Fe}^{3+}+\mathrm{HO}^{-}+\mathrm{HO}^{\bullet} \\
& \mathrm{H}_{2} \mathrm{O}_{2}+\mathrm{UV} \rightarrow \mathrm{HO}^{\bullet}+\mathrm{HO}^{\bullet} \\
& \mathrm{Fe}^{3+}+\mathrm{H}_{2} \mathrm{O}+\mathrm{UV} \rightarrow \mathrm{HO}^{\bullet}+\mathrm{Fe}^{2+}+\mathrm{H}^{+}
\end{aligned}
$$

Adsorption is a technique that removes a compound (adsorbate) from the solution to the adsorbent, which usually is an activated carbon The fixed bed column is an effective process, which uses the concentration difference as the driving force for the process. It allows an efficient adsorbent utilization and results in an effluent with a low adsorbate concentration. The fixed-bed process offers several advantages, such as simplified operation, construction, scale up and process automation and allow the treatment of a large volume of wastewater continuously (Aksu and Gönen, 2004).

Hybrid process, such as photo-Fenton followed by adsorption, has been reported efficiently for the complete removal and/or degradation of some wastewater compounds, such as the leather tanning agent syntan (Thankappan et al., 2014); methyl orange (Saldaña-Robles et al., 2014); organic compounds in landfill leachates (Ramírez-Sosa et al., 2013); methyl methacrylate (Almazán-Sánchez et al., 2014).

The aim of this article was to evaluate the non-azo dye Coomassie Brilhant Blue present in aqueous synthetic solution. A hybrid process composed by photo-Fenton oxidation followed by activated carbon fixed bed adsorption was used to this purpose.

\section{MATERIAL AND METHODS}

\subsection{Material}

Coomassie Brilhant Blue G-250 (CAS: 6104-58-1; chemical formula: $\mathrm{C}_{45} \mathrm{H}_{44} \mathrm{~N}_{3} \mathrm{NaO}_{7} \mathrm{~S}_{2}$; molecular weight: 825,99) was supplied by Isofar Ind. e Com. Produtos Químicos LTDA (Duque de Caxias, RJ, Brazil). The chemistry structure of this dye is show by Figure 1. CBB concentration was determined by measuring the absorbance of the aqueous solution $\left(\lambda_{\max }=554 \mathrm{~nm}\right)$ using a UV spectrophotometer (Shimadzu 1800) and quartz cuvettes in both photo-Fenton and fixed-bed adsorption experiments. The CBB aqueous solution was prepared in distilled and deionized water. 


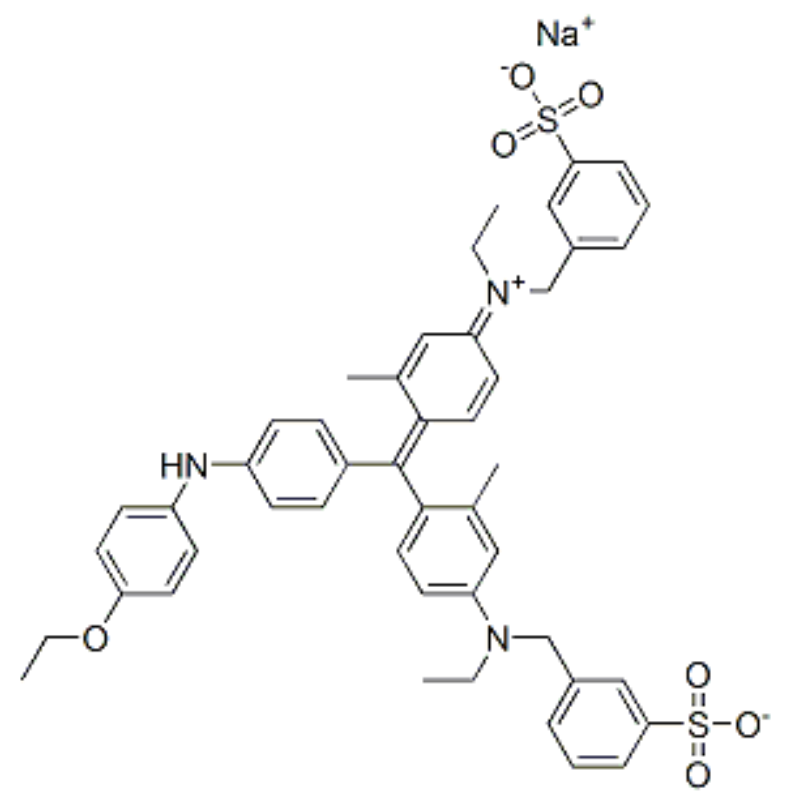

Figure 1 - Coomassie Brilhant Blue G-250 chemistry structure.

The higher concentration which the blue color of the CBB cannot be seen (which is not perceptible by sight) was determinate being $1,0 \mathrm{mg} \mathrm{L}^{-1}$. Then this concentration was defined as the breakthrough concentration.

Activated carbon: The adsorbent utilized in this work was a granular activated carbon derived by coal, named TOG $12 \times 50$, produced by Calgon Carbon.

\subsection{Methods}

Photo-Fenton: The photo-Fenton reaction was conducted in a laboratorial system as shown by Figure 2, according to the methodology described by Igarashi-Mafra et al. (2007). The is composed by a mixing vessel $(500 \mathrm{~mL})$; a magnetic stirrer (model 114, Nova Ética); a peristaltic pump (model Pump drive PD 5002 - Heidolph); UV lamp $(15 \mathrm{~W} ; \lambda=380 \mathrm{~nm}$ ) of $435 \mathrm{~mm}$ in length and $26 \mathrm{~mm}$ in diameter and a spiral glass of $9.0 \mathrm{~mm}$ in diameter.

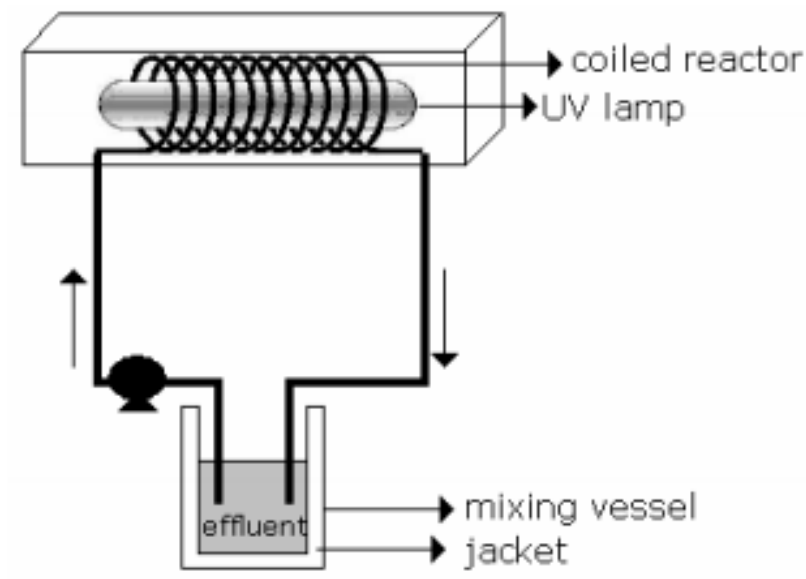

Figure 2 - photo-Fenton experimental unity (Igarashi-Mafra et al., 2007). 
The initial concentration of the synthetic $\mathrm{CBB}$ aqueous solution used was 7,9 $\mathrm{mg} \mathrm{L}^{-1}$. Initially, the $\mathrm{pH}$ of the solution was adjusted to $3,0\left(\mathrm{H}_{2} \mathrm{SO}_{4} 0,1 \mathrm{M} \mathrm{L}^{-1}\right)$. Then, $1,24 \mathrm{~mL}$ of ferrous sulfate heptahydrate solution $\left(\mathrm{FeSO}_{4} .7 \mathrm{H}_{2} \mathrm{O}, 10 \mathrm{~g} \mathrm{~L}^{-1}\right.$, which provided $5 \mathrm{mg} \mathrm{L}^{-1}$ of $\mathrm{Fe}^{2+}$ to the system) and $1,25 \mathrm{~mL}$ of hydrogen peroxide $\left(\mathrm{H}_{2} \mathrm{O}_{2}, 20 \mathrm{~g} \mathrm{~L}^{-1}\right.$, which provided $50 \mathrm{mg} \mathrm{L}^{-1}$ of $\mathrm{H}_{2} \mathrm{O}_{2}$ to the system) was added to the solution. This solution circulated through the glass spiral contained in the photo reactor, at a rate of $200 \mathrm{~mL} \mathrm{~min}^{-1}$, during 60 minutes. The CBB concentration was monitored at regular intervals, and determined by spectrophotometry $(\lambda=554 \mathrm{~nm})$. After the 60 minutes of the reaction, the $\mathrm{pH}$ of the solution was adjusted to 7,0 $\left(\mathrm{NaOH} 0,1 \mathrm{M} \mathrm{L}^{-1}\right)$ in order to inhibit the reaction. The experiments were conducted at room temperature $(298 \pm 1 \mathrm{~K})$.

Fixed-bed: The fixed-bed experiments were conducted in 250-mm-long glass columns with inner diameter of $9.2 \mathrm{~mm}$. Glass spheres ( $3 \mathrm{~mm}$ in diameter) were added to the base of the column to promote uniform flow through the bed. Glass wool was then fixed ( $5 \mathrm{~mm}$ in height) in the column to provide support to the adsorbent. The column was filled with type II water, and activated carbon was added to the column $(5.5 \mathrm{~g})$ which provided a $171 \mathrm{~mm}$ to the bed depth. At the top of the column, glass wool was added ( $5 \mathrm{~mm}$ in height) to avoid fluidization of the activated carbon during the experiment. The column was fed with the $\mathrm{CBB}$ solution (after $\mathrm{pH}$ adjustment to 7,0) obtained after being treated with photo-Fenton oxidation using a peristaltic pump (Masterflex ${ }^{\circledR}$ L/S Digital Drive) employing an upward flow and feed flow rate of $5 \mathrm{~mL} \mathrm{~min}{ }^{-1}$. Samples were collected at regular intervals. The experiments were conducted for 13 hours. A thermostatic bath was used to maintain the temperature of the system at $299 \pm 0.5 \mathrm{~K}$. Figure 3 shows the diagram of the experimental set up.

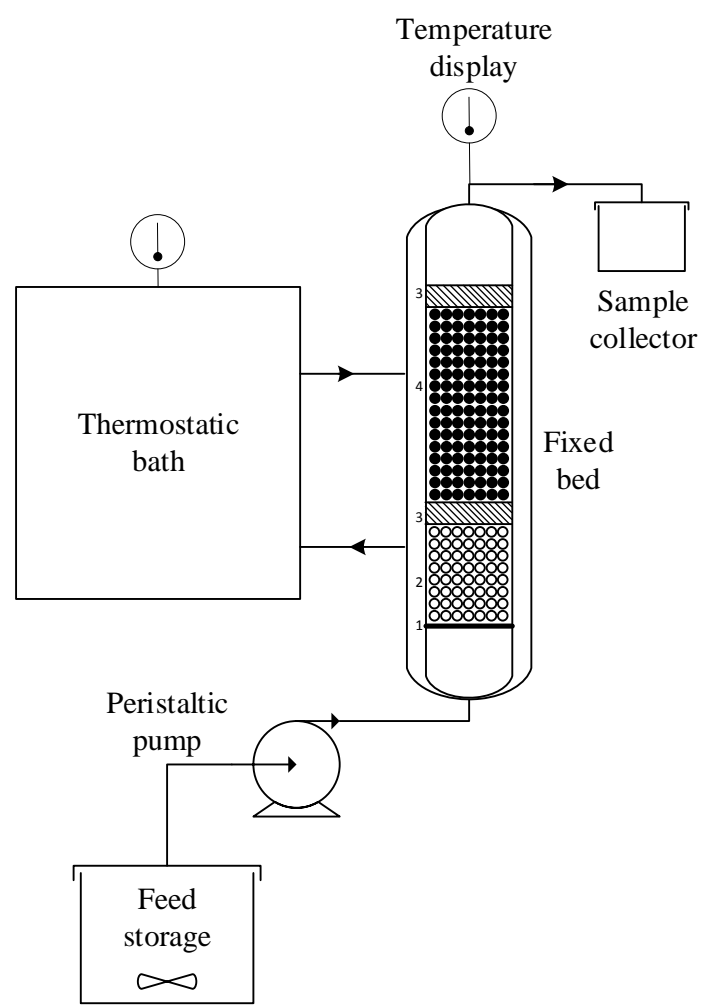

Figure 3 - Schematic diagram of the experimental set up. (1) Column support; (2) glass spheres;

(3) glass wool; and (4) activated carbon. 


\section{RESULTS AND DISCUSSION}

\subsection{Photo-Fenton}

Figure 4a shows the CBB degradation caused by photo-Fenton reaction. The break line was always above the degradation points, which indicates that the effluent was colorful. As can be seen, in the first 15 experimental minutes, the degradation has occurred rapidly, being degraded $65,2 \%$ of the initial dye concentration. After this time, the CBB degradation rate decreased reaching $76,9 \%$ degradation after 60 min of reaction.
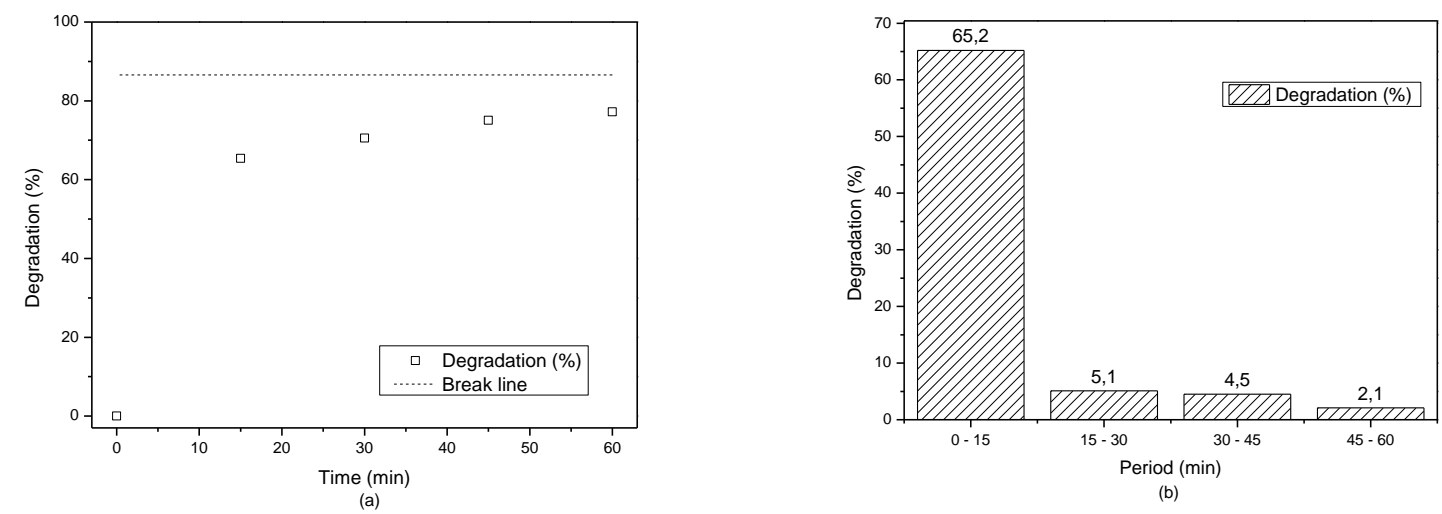

Figure 4 - CBB degradation (\%) by photo-Fenton oxidation.

This reduction in the reaction rate becomes evident when seen in Figure $4 b$, where is represented the $\mathrm{CBB}$ degradation in each period evaluated. In the first period (0-15 minutes) takes place the majority of the dye degradation, however, the degradation reduces over the next periods, being only 2,1\% in the last period studied (45-60 minutes). Extend the reaction for a longer time would cause greater dye degradation; however to this degradation be significant, this time should be very large, which would reduce the efficiency of the process. Caixeta et al. (2013), studied the CBB alcoholic solution degradation using photo-Fenton reaction, removing $~ 70 \%$ in 60 minutes and $\sim 80 \%$ in 120 minutes of the color, which corroborates to the discussion above.

The study of $\mathrm{CBB}$ degradation using the photo-Fenton oxidation degraded the $\mathrm{CBB}$ in $76,9 \%$. However, with the experimental conditions used in this process, has not been possible attend the requirements of the Brazilian legislation, which requires that the effluent be absent of color (in which degradation should reach at least $86,6 \%$ in our study). Therefore, to obtain an effluent absentee in color it was proposed the use of a fixed-bed column filled with activated carbon in order to remove the residual dye obtained after photo-Fenton degradation.

\subsection{Fixed-bed adsorption}

Figure 5 shows the breakthrough curve for the effluent obtained after photo-Fenton oxidation (where $\mathrm{C}_{0}$ is the $\mathrm{CBB}$ concentration before the photo-Fenton oxidation and $\mathrm{C}$ the outlet concentration). From Figure 5 can be seen that the outlet concentration was very low during all the 13 hours of experimental time. $\mathrm{C} / \mathrm{C}_{0}$ was always lower than 0,04 , which indicates high $\mathrm{CBB}$ removing $(95,9 \%)$. This percentage removal was similar to those found in studies where the hybrid photo-Fenton/adsorption process (Ramírez-Sosa et al., 2013; Almazán-Sánchez et al., 
2014; Thankappan et al., 2014).

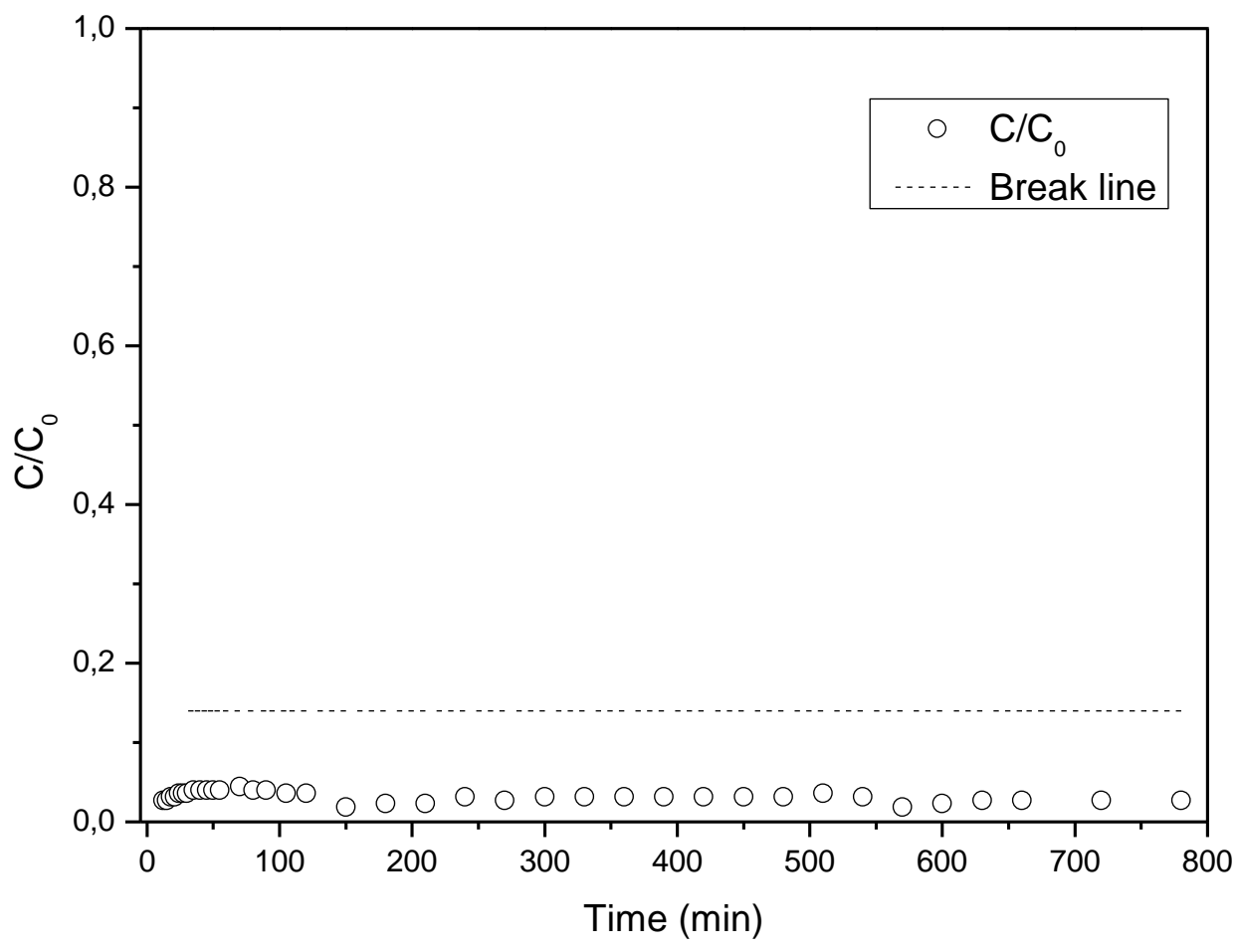

Figure 5 - CBB breakthrough curve by fixed-bed adsorption.

A breakthrough curve usually presents a characteristic $S$ shape, due to the mass transfer forces. In the breakthrough curve obtained in this study, the characteristic $S$ form was not achieved. This is because the activated carbon was not saturated. Even the breakthrough point $\left(\mathrm{C} / \mathrm{C}_{0}=0,14\right)$ was not achieved. This indicates that the bed depth used was high to obtain the complete breakthrough curve.

With the experimental conditions employed, the breakthrough $\left(\mathrm{C} / \mathrm{C}_{0}=0,14\right)$ was not achieved (as shown by the break line). This indicates that during the 13 hours of operation time, the solution were always color absent. Then, the effluent obtained after fixed-bed column can be considered absent color, and therefore satisfies the Brazilian legislation.

\section{CONCLUSIONS}

The hybrid process of photo-Fenton followed by fixed-bed adsorption was investigated in the degradation of a synthetic Coomassie Brilhant Blue aqueous solution in order to remove the blue color and meet Brazilian legal requirements (effluent absent of color). With the photo-Fenton oxidation, $76,9 \%$ of the initial $\mathrm{CBB}$ concentration were degraded, which was not enough to achieve the maximum concentration that is color absent. The photo-Fenton effluent was fed into a fixed-bed adsorption filled with activated carbon during 13 hours, being its effluent always color absent, removing at least $95,9 \%$ of the initial CBB concentration. 
So, the hybrid process photo-Fenton/Fixed-bed adsorption proposed in this study, showed to be efficient to remove the blue color originated by the Coomassie Brilhant Blue.

\section{REFERENCES}

AKSU, Z.; GÖNEN, F. Biosorption of phenol by immobilized activated sludge in a continuous packed bed: prediction of breakthrough curves. Process biochem., v. 39 p. 599-613, 2004.

ALMAZÁN-SÁNCHEZ，P. T.; LINARES-HERNÁNDEZ， I.; MARTÍNEZ-MIRANDA，V.; LUGO-LUGO, V.; OCA, R. M. G. F.-M. de. Wastewater treatment of methyl methacrylate (MMA) by Fenton's reagent and adsorption. Catal. today. v. 220-222, p. 39-48, 2014.

BUKALLAH, S. B.; RAUF, M. A.; ASHRAF, S. S. Photocatalytic decoloration of Coomassie Brilliant Blue with titanium oxide. Dyes Pigm. v. 72, p. 353-356, 2007.

CAIXETA, F. J.; SANTOS, D. V. D.; PIMENTA, A. C.; LEAL, R. C.; RAZABONI, A. M. Degradação de Corante Coomassie ${ }^{\circledR}$ Brilliant Blue em Resíduos Gerados em Laboratórios de Ensino e Pesquisa, via Processo foto-Fenton. In: $36^{\mathbf{a}}$ Reunião Anual da Sociedade Brasileira de Química. Águas de Lindóia - São Paulo, 2013.

CONAMA, RESOLUÇÃO $\mathrm{N}^{\circ}$ 430, DE 13 DE MAIO DE 2011. Available in: <http://www.mma.gov.br/port/conama/legiabre.cfm?codlegi=646>. Accessed on: 20/04/2014.

HAN, R.; WANG, Y.; ZHAO, X.; WANG, Y.; XIE, F.; CHENG, J.; TANG, M. Adsorption of methylene blue by phoenix tree leaf powder in a fixed-bed column: experiments and prediction of breakthrough curves. Desalination. v. 245, p. 284-297, 2009.

IGARASHI-MAFRA, L.; BORTOLETTO , E. C.; BARROS, M. A. S. D.; SORBO, A. C. A. C.; GALliANI, N. A.; TAVARES, C. R. G. Degradation of Odontologic X-Ray Film Developing Wastewaters by Photo-Fenton Process. Int. j. chem. react. eng. v. 5, 2007.

LUCAS, M. S.; PERES J. A. Decolorization of the azo dye Reactive Black 5 by Fenton and photo-Fenton oxidation. Dyes Pigm. v. 71, p. 236-244, 2006.

RAMÍREZ-SOSA, D. R.; CASTILLO-BORGES, E. R.; MÉNDEZ-NOVELO, R. I.; SAURIRIANCHO, M. R.; BARCELÓ-QUINTAL, M.;MARRUFO-GÓMEZ, J. M. Determination of organic compounds in landfill leachates treated by Fenton-Adsorption. Waste Manag. v. 33, p. 390-395, 2013.

RAUF, M. A.; ASHRAF, S.; ALHADRAMI, S. N. Photolytic oxidation of Coomassie Brilliant Blue with $\mathrm{H}_{2} \mathrm{O}_{2}$. Dyes Pigm. v. 66, p. 197-200, 2005.

RAUF, M. A.; BUKALLAH, S. B.; HAMOUR, F. A.; NASIR, A. S. Adsorption of dyes from aqueous solutions onto sand and their kinetic behavior. Chem. eng. j. v. 137, p. 238-243, 2008.

SALDAÑA-ROBLES， A.; GUERRA-SÁNCHEZ， R.; MALDONADO-RUBIO， M. I.; PERALTA-HERNÁNDEZ, J. M. Optimization of the operating parameters using RSM for the Fenton oxidation process and adsorption on vegetal carbon of MO solutions. J. ind. eng. chem. v. 20, p. 848-857, 2014.

SALES, P. F. de; MAGRIOTIS, Z. M.; ROSSI, M. A. L. S.; RESENDE, R. F.; NUNES, C. A. Optimization by Response Surface Methodology of the adsorption of Coomassie Blue dye 
on natural and acid-treated clays. J. environ. Manag. v. 130, p. 417-428, 2013.

THANKAPPAN, R.; NGUYEN, T. V.; SRINIVASAN, S. V.; VIGNESWARAN, S.; KANDASAMY, J.; LOGANATHAN, P. Removal of leather tanning agent syntan from aqueous solution using Fenton oxidation followed by GAC adsorption. J. ind. eng. chem. Article in press. 2014.

WANG, S.; NG, C. W.; WANG, W.; LI, Q.; HAO, Z. Synergistic and competitive adsorption of organic dyes on multiwalled carbon nanotubes. Chem. eng. j. v. 197, p. 34-40, 2012. 